This is an electronic reprint of the original article. This reprint may differ from the original in pagination and typographic detail.

Author(s): Vuorinen-Lampila, Päivi

Title: Gender segregation in the employment of higher education graduates

Year: $\quad 2016$

Version:

Please cite the original version:

Vuorinen-Lampila, P. (2016). Gender segregation in the employment of higher education graduates. Journal of Education and Work, 29(3), 284-308. https://doi.org/10.1080/13639080.2014.934788

All material supplied via JYX is protected by copyright and other intellectual property rights, and duplication or sale of all or part of any of the repository collections is not permitted, except that material may be duplicated by you for your research use or educational purposes in electronic or print form. You must obtain permission for any other use. Electronic or print copies may not be offered, whether for sale or otherwise to anyone who is not an authorised user. 


\section{Gender segregation in the employment of higher education graduates}

Journal of Education and Work 2016, 29 (3), 284-308.

Päivi Vuorinen-Lampila

Finnish Institute for Educational Research, University of Jyväskylä, Jyväskylä, Finland

POB 35

FIN-40014 University of Jyväskylä

Finland

e-mail: paivi.vuorinen-lampila@jyu.fi

This article examines the employment and placement in working life of Finnish higher education graduates (i.e. graduates from universities and polytechnics), focusing on gender equality. It reports a study on gender segregation in higher education and working life, considered in relation to Nordic gender equality policies. The data were gathered via a questionnaire administered to graduates in business and administration $(n=1067)$ and in technology $(n=1087)$, three years after their graduation. The results showed that men were able to secure permanent and full-time employment more often than women, and achieved a better correspondence between their degree and their employment. However, the gender divergence was manifested differently in polytechnics and universities; thus a higher (Master's) university degree seemed to have a compensating influence on the effect of gender. Despite of Nordic equality policies, female and male graduates were placed in the labour market according to tendencies towards gender segregation.

Keywords: gender segregation, higher education graduates, employment, employment success 


\section{Introduction}

The employment of graduates and their placement in the labour market are key issues in current higher education. Growing numbers of graduates are facing difficulties in finding employment, and especially in finding a job corresponding to their education. In parallel with a greater emphasis on efficiency and quality, higher education institutions are increasingly being held accountable in terms of the benefits they provide for the economy and for society. Higher education outcomes have also come under scrutiny as a result of investments in higher education and research, aimed at enhancing competitiveness on a global scale.

Graduate employment and work quality are important outcome measures (Harvey 2001; Schomburg and Teichler 2006, 4). Within Finland, it is also envisaged that the employment of graduates will form one measure in the allocation of funds to higher education institutions, meaning that employment surveys have become a crucial element in the quality assurance system applied to Finnish higher education. Higher education institutions need data on their graduates' employment in order to demonstrate to employers, intending students (and their parents), and society that their degrees provide good value in the labour market. The aim is thus to 'produce' employable students (Harvey 2001; Moreau and Leathwood 2006; Puhakka, Rautopuro, Tuominen, and VuorinenLampila 2012).

The Nordic countries are widely known for their commitment to gender equity and to policies enhancing women's integration in various spaces within public life (e.g. Melkas and Anker 1997). Female participation in higher education and working life is a salient feature of the Nordic states. Women form a majority in Finnish higher education. On a global scale, Finnish women are among the most active participators in working life. However, there is evidence of strong segregation by gender in both higher education and the labour market. Men and women favour different fields of study; they are also placed in different occupations, and occupy different positions (Einarsdottir 2007; Melkas and Anker 1997).

This article looks at the relationship between gender and higher education outcomes in terms of the employment success of graduates. In addition, it elaborates how the gender equity of higher education outcomes varies between the polytechnic ${ }^{i}$ and university sectors, and between holders of degrees from the study fields of business and technology. Overall, it examines how gender is involved in graduates' employment, and whether it differs between polytechnic and university graduates, or by degree.

The issue is interesting for two main reasons. (i) Most Finnish studies on graduate employment have so far ignored the gender equality aspect, or at least have not investigated it systematically (e.g. Kivinen, Hedman and Kaipainen 2007: Korhonen and Sainio 2006; Vuorinen and Valkonen 2007; see also Raffe 2008). This is surprising, given that studies from other contexts indicate that females and males with same educational level tend to achieve different kinds of employment quality and status in working life (e.g. Melkas and Anker 1997; Smyth 2002). There seem to be good reason to argue that studies that do not take into account gender factors are likely to produce a somewhat simplified picture of graduate employment. (ii) The context of graduate employment has changed in recent decades. New graduates jostle for jobs with the mass of other graduates who have achieved the same degree. At the same time, accelerated competition continues to emphasize economic efficiency in labour costs, and it is plausible that this factor will have differing consequences for the employment of female and male graduates. Overall, it appears that the problems of graduate employment have increased, and that the resulting insecurity may, in a number of ways, be reflected in the employment of higher education graduates. In this situation, one can also hypothesize that the changes will have different effects with respect to the employment of women and men. 


\section{Gender equality in Finnish higher education and working life}

To understand how, within Finland, gender relates to studies pursued in higher education and to graduate employment, it is necessary to consider how gender and participation in education and working life are intertwined in Finland - bearing in mind that Finland is commonly regarded as an exemplary country in its welfare and gender equality policies.

\section{The welfare state promotes equality}

The structures of employment and the transition from education to working life are influenced not merely by the education system, but also by the organization of labour markets, by the social welfare system, and by family structures (Raffe 2008; Walther 2006). Thus, the increased participation of women in paid employment, politics, and higher education over a relatively short time span can be seen as linked to the Nordic welfare state agenda (Brandth and Kvande 2001).

A notable feature of Nordic policies of equality, which have increased the participation of women at all levels of education, is that they have rapidly enhanced the qualifications obtained by women. In parallel with the expansion of higher education, the participation of Finnish women in higher education has increased to such an extent that women now form a majority in both higher education sectors (64\% of university graduates and $67 \%$ of polytechnic graduates in year 2000). The feminization of higher education has been seen as a feature of mass higher education (Kivinen, Hedman and Kaipainen 2007; Kivinen and Nurmi 2009). At the present time, Finnish women of working age are more educated than men. The difference is most evident in the younger age groups. Thus, among young adults (aged 25-34), 41\% of women have a higher education degree as opposed to 26\% of men (Ministry of Education and Culture 2010). The difference between the genders is indeed striking.

The rising levels of education have further enhanced a long tradition of participation in employment on the part of Finnish women. The employment rate for women was $68 \%$ in 2009, contrasting with $58 \%$ in the EU countries as a whole. The employment gender gap was narrowest in Finland and Estonia among all the EU countries (Eurostat Labour Force Survey 2010; Julkunen and Nätti 1999, 48-49). Among the Nordic countries, Finland has particular features that have made it easier for women to participate in working life. iii Finland can be seen as a country with a strong emphasis on a breadwinner model wherein both spouses have paid work and earnings - a dualearning model. Institutional arrangements such as family leave legislation and a public day-care system have been crucial for female labour market participation. All children under school age are guaranteed a municipal day care-place (Haataja and Nyberg 2006; Julkunen and Nätti 1999, 48; Tammelin 2009). Maternity leave is of fairly long duration, as is paternity and parental leave. Following parental leave, parents have the right to a period of care leave until the child is three years of age. There is flexibility in the way in which leaves are taken: the parents are free to split them (Ellingsæter and Leira 2006, 20-21; Haataja and Nyberg 2006).

As a counter-trend to arrangements that contribute to female labour market participation, one can observe tendencies in working life towards tight timetables and non-regulated working cultures, with corresponding demands for efficiency and increased productivity. The drive for efficiency requires long working hours and an intense commitment to one's work (Børve 2007; Brandth and Kvande 2001). Demands of this kind may be problematic, especially in the case of parents with small children. This issue is highly relevant to the employment of new graduates. The first years after graduation are a period in which major changes may occur in people's private lives. It is a time when many young people get married, have children, and/or buy their own home for the first time (Dæhlen 2007). The European study by Wolbers (2007) reveals that more than one third of those 
graduates who were not married at the time of graduation were married 3-4 years later. In Finland in 2009 the percentage of marriages was clearly highest in the age group of 25-29 years (Nikander 2010) to which many Finnish higher education graduates belong. For people within this age group, issues of security may be crucial. The insecurity of working life has been viewed by the late modern theorists Bauman (2000), Beck (1992), and Giddens (1991) as relating to all employees; however, the phenomena in question can have a particularly far-reaching influence on the major decisions taken by new graduates. In this phase of life, monetary rewards and/or job security may become more important because of family and other financial commitments (Dæhlen 2007).

\section{Gender segregation erodes equality}

In spite of the high educational level of Finnish women, educational choices are strongly differentiated by gender. At all educational levels, the fields of education and health care are dominate ${ }^{\mathrm{iv}}$ by women, whereas there is a male majority in the fields of engineering and natural sciences. In addition, female and male students in the same field tend to choose different study programmes and to aim at different specializations. Gender-specific study choices have a major influence on labour market segregation. To a large extent, gender differentiation within the education system is paralleled by gender segregation in the labour market (Duquet, Glorieux, Laurijssen and van Dorsselaer 2010; Iannelli and Smyth 2008; Einarsdottir 2007; Smyth 2002; Støren and Arnesen 2007).

If one accepts that gender segregation exists in the labour market, several implications follow. In the first place, there is reason to see it as problematic for both women and men. At the very least, the lack of one or other gender is a hindrance to social and societal balance, assuming that the views of both genders are needed in all occupational and societal fields. More specifically, from women's point of view, gender segregation has been regarded as the most important factor contributing to gender inequality in working life ${ }^{\mathrm{v}}$. The phenomenon can be divided into horizontal and vertical segregation. Horizontal segregation implies that men and women work in different occupations, sectors, and workplaces. In Finland, such segregation is seen in particular in the gender divisions that exist between the public sector (mainly women) and the private sector (mainly men). Vertical segregation is seen in the phenomenon of male and female employees having different positions in the hierarchy of working life. Men are more likely to reach higher positions and to progress rapidly in their careers; in addition, there is a clear gender wage gap. It is also the case that the position of women in the labour market is weaker than that of men. Females are more often found in temporary and part-time employment, and the status return on women's education is significantly lower than the return for men (Anker 2001; Duquet et al. 2010; Kreimer 2004; Melkas and Anker 1997). According to several studies, a similar situation exists among higher education graduates (Duquet et al. 2010; Einarsdottir 2007; Kivinen and Nurmi 2009; Naumanen 2002; Prix 2009; Smyth 2002). However, in Finland, the proportion of people working in part-time employment is fairly small for both women and men.

Gender segregation in education and in the labour market has decreased over time. Women have increased their share in previously male-dominated areas of study (Berggren 2008; Støren and Arnesen 2007; Vuorinen-Lampila and Valkonen 2012), along with the increased participation of women in higher education which has led to less vertical gender segregation. In line with this trend the proportion of women in management level occupations increased between years 2001-2009 from $30 \%$ to $35 \%$. The proportion of females has shown a particular rise in highly-demanding occupations. Thus, in 1975, 28\% of Finnish physicians were females, while in 2010, the proportion was $59 \%$. Despite this, in 2010, the income of female physicians was $84 \%$ of the income of their male colleagues. Overall, there has been hardly any change in wage differences between the mid- 
70s and 2010. Although women have become better represented in management, in $200965 \%$ of managers were still men. (Idman 2011).

Looking at the overall situation, one can say that gender segregation still exists to a considerable extent both in education and in the labour market (Kreimer 2004; Melkas and Anker 1997; Støren and Arnesen 2007), even if, as mentioned above, highly qualified women have been able to benefit from the growth of professional employment, with a corresponding move towards gender parity in the labour market (Kreimer 2004). In the case of higher education graduates, one interesting point is that in spite of the vigorous equality policy pursued by Finland, the occupational statuses of higher education degree-holders in Finland show a stronger bias in favour of men than in other European countries (Kivinen and Nurmi 2009). This may partly be due to a stronger differentiation by field of study in Finland, where gender and social class differences in levels of educational attainment are lower than elsewhere in Europe (Iannelli and Smyth 2008).

\section{Indicators of graduate employment}

Higher education graduates' employment and their placement in working life can be examined via various indicators, both quantitative and qualitative. This study made use of the quantitative criteria of graduate employment success presented by Teichler $(1999,2007)^{\mathrm{vi}}$. These criteria fall under three major categories: the fluency of the transition to working life, the stability of the person's employment, and the quality of the person's work, as follows:

(1) the transition from higher education to the world of work: measured in terms of a smooth transition to employment, including short intervals between graduation and employment;

(2) employment: a low unemployment rate, job security, a low percentage of non-regular or precarious employment (temporary, part-time, or short-time employment), the social respectability of the job;

(3) work: links between study and employment; these involve:

a) the vertical success of graduates' placement in working life, including a high return on educational investment, i.e. a high rate of graduates adequately employed;

b) the horizontal success of graduates' placement in working life, including a close linkage between the field of study and the occupation.

These three indicator groups are here used in order to measure graduates' employment success. However, due to increasing complexity in the relationship between higher education and working life, there is a need for a broad range of measures within each group if one is to study graduates' professional success (Schomburg 2007). For the operational purposes of the present study, the indicators are specified as:

(1) Transition: the fluency of the transition from higher education to the world of work The transition period has traditionally been defined as having an intermediate status between fulltime schooling and full-time employment. In practice, the transition has become more complex, and the borderline between education and work has become less clear (Allen and van der Velden 2007). The indicators that are relevant to the transition in this study are:

a) the employment situation at the moment of graduation (adequate employment); whether the respondents had a job corresponding to their degree at the time of graduation or not;

$b$ ) the length of the job search after graduation in months (the question was only for those respondents who did not have adequate employment at the time of graduation); 
c) unemployment experiences after graduation (whether the graduate had been unemployed or not).

\section{(2) Employment}

The regularity of employment (involving full-time work and a permanent contract) is considered to be the most fundamental indicator of employment success. In measuring the stability of employment, two additional indicators ( $\mathrm{b}$ and $\mathrm{c}$ below) are used. The indicators of employment are thus:

a) regularity (full-time or part-time), and permanence (regular or temporary contract) of employment;

b) employment status three years after graduation (the percentage of graduates in a paid job, the unemployment rate);

c) the employment sector (private or public/third sector).

(3) Work: the links between study and employment: vertical and horizontal success of placement in working life:

a) the position of graduates in the employer's organization (management level, clerical employee, shop-floor level, other position);

b) the proportion of graduates working in an expert position; vii

c) the correspondence between graduates' degrees and employment by level and field (see more detailed reference to this indicator in the Results section).

It has been pointed out (e.g. Berggren 2010) that defining the correspondence between graduates' degrees and the employment they have achieved is complicated. There have been many changes and reforms both in higher education and in the labour market, and these changes have occurred fairly rapidly. There are a number of objective measures that can be used in matching education and occupation; however, these require, for example, specific data on the occupation and on the requirements of certain positions (Berggren 2010). Overall, this means that any objective measuring process will be very challenging. In compiling our questionnaire we used a method based on graduates' subjective perceptions.

\section{Aims and research questions}

The aim of the present study was to investigate graduates' employment success from the gender point of view. More specifically, the aim was to examine these questions:

(1) How does the employment success of higher education graduates differ by gender?

(2) What kinds of differences relating to gender are found between university and polytechnic ${ }^{i}$ graduates, between study fields (business and administration vs. technology and transport), and between graduates with different degrees?

\section{Research design}

The data were drawn from a survey of graduates' employment which was conducted in 2005 . The data were collected via a questionnaire addressed to graduates in two fields of study:

(i) technology and transport (= Bachelors of Engineering [in Finnish: AMK-insinöörit], and Masters of Science in Technology (and Architecture) [in Finnish: diplomi-insinöörit (arkkitehdit)];

(ii) business and administration (= Bachelors of Business Administration [in Finnish: tradenomit], and Masters of Science in Economics and Business Administration [in Finnish: kauppatieteiden maisterit]). 
These fields of study were chosen since corresponding degrees can be gained in these fields in both polytechnics and universities, thus making comparisons possible. In addition, these fields are among the largest study fields in both sectors, covering high volumes of graduates (in the universities $31 \%$ of graduates; in the polytechnics $55 \%$ of graduates). The questionnaire was constructed on the basis of previous Finnish studies conducted on entry to higher education and graduate employment (e.g. Stenström 2006; Vuorinen and Valkonen 2005). The survey was carried out three years after the graduates had completed their studies. Previous research suggests that the transition to working life tends to be marked by high job mobility in the years immediately following graduation. Three years was regarded as a period long enough to examine the permanent placement of graduates in working life.

The identity numbers of all graduates from the year 2002 in study fields of business and technology were obtained from the higher education institutions, and the addresses of graduates were attached by the Population Register Centre. The sample was targeted at covering $33 \%$ of all Finnish graduates from Finnish-speaking universities and polytechnics (thus excluding Swedishspeaking higher education institutions ${ }^{\text {viii) }}$ in the two broad study fields for the year 2002. The method applied was systematic random sampling. In practice this required sampling about 1000 graduates from each degree group. The purpose was to obtain sufficiently large number of respondents of each degree (after the likely drop-out effect), to enable valid data analyses with results generalizable to the population. In relation to the target, the overall response rate of $56 \%$ $(n=2154)$ turned out to be fairly good. The questionnaires were posted to respondents by ordinary mail. As is typical in questionnaire surveys, women were more active respondents than men: $59 \%$ of female graduates and $53 \%$ of male graduates returned the questionnaire $(p<0.001$; Table 1$)$. The women's response rate was also higher for each degree group.

The university graduates responded more often than the polytechnic graduates (57\% vs. 53\%; $p=0.043)$. Considered by degree, all the response rates were fairly good (52-59\%), but there was nevertheless a statistically significant difference between degree groups $(p=0.015)$. The technology Masters' response rate was the highest, and the technology Bachelors' response rate was the lowest, with the business studies response rates occupying an intermediate positions. The differences in response rates by age or by the university or polytechnic from which the respondent had graduated were negligible. Overall, one can therefore consider the sample to be representative with respect to gender, age, degree and higher education institution. However, the relation between response rate and employment success remains unknown, and it is possible, for example, that unemployed graduates have lower-than-average response rates, which then might enhance the picture of the employment success given by the data set. On the other hand, graduates who have succeed very well might have been too busy to respond.

Table 1 here

ix (see endnote for Table 1)

In the fields examined here gender segregation is highly evident in the male-dominated field of technology, within both higher education sectors. In the polytechnics the percentage of males in technology is even higher (79\%) than in the universities (76\%). In the field of business, the proportions of men and women are in balance at the university level; however, at the polytechnic level the field of business is clearly female-dominated (74\%). The gender divisions are typical of these fields of study (Einarsdottir 2007; Johnston and Little 2007). However, it should be noted that in other European countries the business field is gender-balanced in both higher education sectors, not merely in the universities, as is the case in Finland (Kivinen and Nurmi 2009; Prix 2009). 
The results are presented via descriptive statistics: frequencies, percentages, and arithmetic means. The significance of differences was tested by the chi-square test and by analysis of variance. The probability levels of under $5 \%$ were taken to be statistically significant $(p<0.05)$.

\section{Results}

The results are reported in relation to the research questions, in the same order in which the indicators of graduates' employment success were presented above. The numerical results are presented in Table 2. The two research questions are dealt with together, in the course of reporting the results for each indicator.

\section{Transition to employment}

\section{Employment situation at the time of graduation}

The respondents were asked about their employment situation at the time of their graduation and three years after it. Within this part of the questionnaire the respondents were asked about the adequacy of their employment, that is, the extent to which the employment corresponded to their degree. Respondents were asked to respond according to their own perceptions. At the moment of graduation, $68 \%$ of the respondents had a job corresponding to their degree. Thus, they had started to work prior to graduation. The percentages differed between women and men $(p<0.001)$. The percentage of men who had adequate employment at the time of graduation was clearly higher (74\%) than that for women $(60 \%)$ in all degree groups (Table 2, 1a).

Length of the job search

As indicated above, about two-thirds of the graduates already had an appropriate job at the time of graduation. One third were still continuing their job search. The respondents who did not have a job at graduation had been searching for a job for 7.7 months on average. There were no statistically significant differences by gender. Overall, it took quite a long time for new graduates to find a job if they did not have a job prior to graduation. One can say that a period of seven to nine months of job searching is a long period in a young person's life, and also a long time to live without earned income. However, a respondent might have some job other than the appropriate one, while waiting for the appropriate one to come up.

\section{Unemployment experiences}

One quarter $(25 \%)$ of the respondents had experienced unemployment during the period of three years from graduation (Table 2,1c). There had been fierce competition for jobs. For many graduates, the job search had taken time, and was experienced as a laborious endeavour.

There was a statistically significant main effect of gender in the frequency of unemployment experiences $(p=0.002)$. Female graduates had been unemployed more often than male graduates $(30 \%$ vs. $21 \%)$. However, there was also an interaction between gender and degree $(p=0.022)$. Thus, there would appear to be a difference between genders, but also a relationship with the degree, or in this case with the field to which the degree belongs. In the field of business there was only a minor difference between genders. In technology the difference between women and men was considerable: the percentages of female graduates who had been unemployed were almost double compared to those of male graduates. In the field of technology it was much more problematic for female graduates to start their career than it was for their male counterparts.

Table 2 here 


\section{Employment}

\section{Regularity and permanence of employment}

Overall, almost all of the graduates who were employed had full-time jobs (96\%). The only exceptions were the Bachelors of Business Administration, of whom 90\% had a full-time job and $10 \%$ worked part-time. There was a statistically significant main effect of gender $(p=0.002)$ and also an interaction between degree and gender $(p=0.019)$ in relation to the regularity of the employment. Hence, the effect of gender was different for holders of different degrees. In the field of technology and among Masters of Science in Economics women and men were engaged in full-time employment fairly equally. Among Bachelors of Business Administration male graduates' full-time employment was at the same level as that of holders of other degrees, but females' full-time employment was clearly at a lower level.

Temporary employment has recently become fairly common among Finnish higher education graduates. In spite of this, the graduates in this study were mostly employed in permanent jobs $(84 \%)$. Once again there was a statistically significant difference by gender $(p<0.001)$, and a statistically significant interaction between degree and gender $(p=0.031)$. In our data, $78 \%$ of the female graduates and $88 \%$ of the male graduates had a permanent job. In addition, the effect of gender was stronger among technology Masters and business Bachelors; in these groups men were considerably more likely than women to have permanent employment. There was a similar trend among Bachelors of Engineering and Masters of Science in Economics but the differences between women and men were not so striking in these cases.

Although the respondents in the field of technology mostly had a permanent job, the percentage of female technology Masters who had regular employment was observed to be surprisingly low compared to the other graduates in the same study field. This may in part be explained by their frequent employment at the university as researchers or as PhD students. The occupational title 'researcher' was the most common title among technology Masters. Here it should be noted that in the universities it is normal to have temporary contracts.

\section{Employment status three years after graduation}

The great majority of respondents were in paid work (90\%) three years after graduation. Male graduates were more often in paid employment than female graduates (92\% vs. 87\%; $p=0.017)$. Entrepreneurship was almost solely the choice of men, whereas women continued their studies more often than men. The unemployment rates overall were very low, and the unemployment rates did not differ by gender (3\% vs. $2 \%$ ). Female graduates' employment status was more often 'other'; this indicates that they were more frequently out of the labour force for reasons such as maternity leave or care leave.

Although the unemployment rate overall was very low - as is typical of higher education graduates in Finland - it was possible to detect hidden indicators of employment problems. One such indicator may indeed appear in the proportion of female graduates who (as mentioned above) were on maternity or care leave (hence with employment status 'other'). It can be assumed that it is easier for highly educated women to have the status of being on maternity or care leave rather than that of being unemployed. The inference could be that it is precisely the onset of employment problems that may prompt a young woman to choose to have a child. In open-ended responses some of the respondents reported that difficulties in finding employment were the factor that had encouraged them to have a family before embarking on a long drawn-out search for employment.

Another hidden indicator of employment problems was the proportion of graduates who were doing studies in addition to paid work (Table 2, 2b). Especially interesting are the high percentages (33\% of women and $28 \%$ of men) of Masters of Science in Technology who had 
embarked on $\mathrm{PhD}$ studies. In practice, most of them worked at the university as researchers or as $\mathrm{PhD}$ students. In other words they were in paid employment but were aiming at a $\mathrm{PhD}$ at the same time. Given that the wage level of persons with a technology Master's degree is much higher in the private sector than in the universities, one can assume that it is the problems in finding employment in private companies that can make graduates choose a university post to the extent observed.

\section{Employment sector}

About three out of four graduates in the fields of technology and business found their employment in the private sector. There was a significant difference by gender $(p<0.001)$. In line with the normal tendency, men found employment in the private sector more often than women (80\% vs. $71 \%)$. The employment sector of the graduates was connected with the permanence of their job: in the private sector the contracts are usually regular ('until further notice') whereas temporary contracts are more common in the public sector. Because female graduates more frequently took up posts in the public sector (and also the 'third' sector, meaning foundations, associations, co-operatives, etc.) ${ }^{\mathrm{x}}$, they tended to have fewer permanent contracts.

\section{Work}

The position of graduates in the employer's organization

The results showed that within the employer's organization a majority of the graduates were engaged in clerical jobs (61\%). There was again a statistically significant difference by gender $(p<0.001)$. Men were more likely to have a managerial post, whereas women were more frequently clerical or shop-floor employees. An interesting phenomenon (considering the lower status of shopfloor jobs) was the relatively high proportion of shop-floor workers among both female and male Bachelors of Business Administration (females 29\%, males 25\%) and female Bachelors of Engineering (23\%). In addition, among the polytechnic graduates but not the university graduates, there was a difference between genders in the proportion of those who worked at shop-floor level.

\section{Correspondence between degree and employment}

The respondents were asked about their own perceptions of working as an expert ${ }^{\mathrm{vi}}$. A majority of all graduates $(81 \%)$ considered that they were carrying out the duties of a professional. The proportion varied clearly between genders $(p<0.001)$. Male graduates were working in an expert position more often than female graduates ( $86 \%$ vs. $73 \%$ ). However, in addition to this main effect of gender, there was an interaction between degree and gender $(p=0.002)$. In both groups of university graduates, the female and male respondents had taken up an expert post to a more equal extent than in both groups of polytechnic degree holders. A particularly notable result was that the female Bachelors of Engineering were much less likely to find an expert job than their male counterparts.

In two items in the questionnaire the respondents were asked to assess the equivalence between their education and job, both by level and by field. Likert scales were used for this $(1=$ very poorly, $5=$ =very well). On the basis of those Likert-scale responses, four categories were formed: (a) both correspond well, (b) the level corresponds well but the field poorly, (c) the field corresponds well but the level poorly, and (d) both correspond poorly. Table 2 shows the percentages of graduates whose employment and education corresponded well by both level and field. In order to show the results more clearly the other three categories are not included in the table.

In all, $85 \%$ of graduates thought that there was a good correspondence between their degree and their job. The analysis showed that the difference between genders was not statistically significant $(p=0.073)$. However, there was a significant interaction between gender and degree 
$(p=0.041)$. This means that there were minor differences between women and men in all degree groups except the Bachelors of Engineering. The percentage of male engineering graduates who perceived their degree and job as corresponding well was $86 \%$; the percentage among their female colleagues was $74 \%$.

The results above, showing similarities between genders (with the exception of technology Bachelors), were at variance with other results of this study, which indicated weaker employment success among females. Here it should be noted that the informants' perceptions of a correspondence between their education and their work were likely to depend on their overall expectations. Thus, if females' expectations were lower in general, they could have assessed their employment quality differently from their male colleagues, whose expectations were higher. It is important to bear in mind that respondents with the same occupational title could perceive the quality of their employment in very different ways.

\section{Concluding discussion}

The study aimed to explore (i) the differences of the employment success of higher education graduates by gender. Further, it aimed to examine (ii) gender-related differences in the employment of university and polytechnic graduates, on different study fields, and between graduates with different degrees. The theoretical framework of the study was formed by gender segregation research and by the gender equality policies of Finland which was seen as representing the Nordic welfare model.

The results suggested, first of all, that there were major differences between genders in the employment success of graduates, and that these differences were in favour of men. At the time of graduation men had adequate employment more often than women. Three years after graduation men were more likely to have a full-time job and a permanent contract. Men also reached higher organizational positions in the companies they worked for, and achieved expert positions more frequently. On seven out of ten indicators the employment outcomes of female graduates were at a lower level than those of their male counterparts (Table 3). All in all, based on the various indicators, the employment success of male graduates emerged as significantly better than that of their female colleagues.

Secondly, the analysis revealed five interactions between gender and degree(s), and these, too, were in favour of men (Table 3). Gender divergence appeared to be dissimilar in the two higher education sectors studied. This meant that possessing a higher level degree (a university Master's degree) had, to some extent, a compensating influence on the gender effect. Thus, on some indicators the differences between male and female graduates were smaller among university degree holders. Certain indicators also showed differences only among polytechnic graduates, or in a particular group of polytechnic graduates.

Table 3 here

The results imply that female and male graduates had a differing start in the first steps of their working life, right from graduation. The results are thus in accordance with previous studies (e.g. Einarsdottir 2007; Kivinen and Nurmi 2009; Naumanen 2002; Smyth 2002). It is worth noting that men gained considerable benefit from their gender even in the female-dominated degree group of business Bachelors, as well as in the gender-balanced group of business Masters and the maledominated technology degree groups. Overall, the findings from degree groups with different gender proportions indicate that the gender differences in labour market outcomes cannot be explained merely by differing choices in fields of study or degree programmes (cf. Duquet et al. 
2010). Men have been more successful in the labour market irrespective of whether they have graduated from male-dominated, female-dominated, or gender-balanced study fields. Conversely, women have been less successful irrespective of the gender distribution of their study field. At the same time, it should be noted that differing specializations (within degrees) of females and males with the same degree may partly underlie the disparities in male and female labour market outcomes.

In terms of the gender differences between higher education sectors, the results suggest that it is even more important for women to earn a higher-level (university) education than it is for men. A polytechnic education seems to be more adequate for men in terms of achieving good quality employment and a secure status in the labour market. Women need to have a university degree in order to achieve equally favourable employment outcomes.

The results indicating these clear differences between genders are strongly consistent with theories of gender segregation (Anker 2001; Kreimer 2004; Melkas and Anker 1997). For new graduates, the transition to working life seemed to be gender-segregated right from the completion of studies. Despite the equality policies characteristic of a Nordic welfare state (involving female domination at all levels of education, and the active participation of women in working life), the gender segregation principle defines the placement of female and male graduates from universities and polytechnics in the Finnish labour market, and in working life.

Such a strong intertwining of gender segregation with the employment success of higher education graduates and with their placement in working life may come as a surprise in the context of the Finnish welfare state. The reversal of gender positions after entry to working life is striking; after all, girls perform better than boys at school, and in higher education women complete their studies a good deal more frequently than men (Vuorinen-Lampila and Valkonen 2012, 207, 211), thus predominating in the both higher education sectors studied. Thereafter, when (former) students enter the labour market the roles are reversed: men benefit from their gender from the very beginning of their careers. Finland is often perceived as exemplary in terms of gender equality, but one can see that in the labour market there is still much to do if equality is to be achieved. In practise it seems that even though Finland is a leader in gender equality in employment, there are clear differences in employment success between men and women even if the differences are smaller than in many other countries.

In seeking reasons for the inequality in the labour market it is worth noting again that the study fields selected in this study were business and technology. Graduates from these fields are often employed in companies which demand long working hours and intense commitment to the work- features seen as enhancing effectiveness and global competitiveness (Børve 2007; Brandth and Kvande 2001). This is in particular emphasized in the highly competitive operations of private sector companies. One can see that in an era when efficiency is emphasised, the arrangements put in place by the welfare state may have an ambivalent effect on women's employment. On the one hand, these arrangements are considered to be part of the general equality policy, and to enhance both parents' possibilities to combine work and family life. On the other hand, the financial obligations placed on employers by family leave arrangements may lessen employers' willingness to employ women and may thus have a negative influence on female employment (Standelmann-Steffen 2008). Women may be regarded as higher-cost workers because of higher indirect labour costs, and the bearing of these costs by employers may become a cause of gender discrimination (Anker 2001). In particular, such costs may have a crucial influence on private sector employers' willingness to engage female employees, who are seen as an 'expensive risk'. That is exactly how some female respondents reported on their experiences in job searches (Vuorinen and Valkonen 2007). Given that the number of births in Finland increased between years 2002 and 2005 (from 55,555 to 57,745), and that the same trend appears to be continuing (Statistics Finland 2010), this aspect clearly remains a matter of considerable importance. 
The results seem to be in line with the results of Duquet et al. (2010) which suggest that family formation has a negative impact on the labour market position of women, but not on that of men. Thus, there would appear to be a danger that the growing emphasis on effectiveness and global competition will (further) weaken the situation of women in the labour market. In this regard, one can suggest that the position of men and women in the Finnish labour market would become more equal if the costs of family formation were borne between the employers of both parents, or by society (along the lines of Sweden).

The data for this study were collected almost ten years ago. Nevertheless, the results remain relevant, since the employment situation of higher education degree holders has, at the very least, not improved since the year of data collection. The reader will note that in order to reach firmer conclusions on the trends for males and females in the labour market situation one would require comparative data from a newer graduate cohort. Thus, a follow-up study is needed in order to analyse trends, and to determine the impact of economic aspects on female and male graduates' employment over a longer period.

As mentioned above (in Research design -section), in terms of generalizing the results and in terms of reliability, it should be borne in mind that the response rate differed clearly between genders, as is typical of questionnaire surveys in general. Given that the relation between response activity and employment success remains unknown, it is possible, for example, that the more selective responses of males may have slightly enhanced the overall picture of their employment success. Nevertheless, the data for this study had the merit of being drawn from a representative, random, nationwide sample of business and technology graduates in both sectors of higher education (i.e. universities and polytechnics) from the graduation year in question. Overall, one can be reasonably confident that the data were reliable in terms of detecting the effects of gender on the types of employment achieved by higher education graduates, and of allowing comparisons between sectors. In addition, the results would appear to be generalizable to the national level. 


\section{References:}

Allen, J., and R. van der Velden. 2007. Transition from higher education to work. In The careers of university graduates': Views and expertise in comparative perspectives, ed. U. Teichler, 55-78. Dordrecht: Springer.

Anker, R. 2001. Theories of occupational segregation by sex: An overview. In Women, gender and work: What is equality and how do we get there?, ed. M. F. Loutfi, 129-155. International Labour Office: Geneva.

Anxo, D., G. Bosch, and J. Rubery. 2010. Shaping the life course: A European perspective. In The welfare state and life transitions. A European perspective, eds. D. Anxo, G. Bosch, and J. Rubery, 1-70. Cheltenham: Edward Elgar Publishing.

Bauman, Z. 2000. Liquid modernity. Cambridge: Polity Press.

Beck, U. 1992. Risk society: Towards a new modernity. London: Sage.

Beechey, V. 1987. Unequal work. Norfolk: Thatford.

Berggren, C. 2008. Horizontal and vertical differentiation within higher education - Gender and class perspective. Higher Education Quarterly 62: 20-39.

Berggren, C. 2010. The influence of higher education institution on labour market outcomes. Europen Education 42, no. 1:61-75.

Børve, H. E. 2007. Pregnant bodies. Norwegian female employees in global working life. European Journal of Women's Studies 14, no. 4: 311-326.

Bradley, H. 1989. Men's work, women's work. A sociological history of the sexual divisions of labour employment. Cambridge: Polity Press.

Brandth, B., and E. Kvande. 2001. Flexible work and flexible fathers. Work, Employment and Society 15, no. 2: 251-267.

Dæhlen, M. 2007. Job values, gender and profession: A comparative study of the transition from school to work. Journal of Education and Work 20, no. 2: 107-121.

Duquet, N., I. Glorieux, I. Laurijssen, and Y. van Dorsselaer. 2010. An unfinished job? The effect of subject choce and family formation process on labour market outcomes of young men and women. Journal of Education and Work 23, no. 4: 319-338.

Einarsdottir, T. 2007. "On different tracks": The gendered landscape of educational and occupational paths amongst European graduates. In Careers of university graduates. Views and experiences in comparative perspectives, ed. U. Teichler, 179-194. Springer: Dordrecht.

Ellingsæter, A. L., and A. Leira, eds. 2006. Politicizing parenthood in Scandinavia. Gender relations in welfare states. Bristol: The Policy Press.

Esping-Andersen, G. 1990. The three worlds of welfare capitalism. Princeton: Princeton University press.

Eurostat Labour Force Survey. 2010. http://epp.eurostat.ec.europa.eu/cache/ITY_PUBLIC/ 3-04082010-BP/EN/3-04082010-BP-EN.PDF (accessed June 20, 2012)

Giddens, A. 1991. Modernity and self-identity. Cambridge: Polity Press.

Haataja, A., and A. Nyberg. 2006. Diverging paths? The dual-earner / dual-career model in Finland and Sweden in the 1990s. In Politicizing parenthood in Scandinavia: Gender relations in welfare states, eds. A. L. Ellingsæter, and A. Leira, 217-239. Bristol: The Policy Press.

Harvey, L. 2001. Defining and measuring employability. Quality in Higher Education 7, no. 2: 97-109.

Hirdman, Y. 1988. Genussystemet - teoretiska reflexioner kring kvinnors sociala 
underordning [Gender system - theoretical reflections of social undervaluation of women]. Kvinnovetenskaplig tidskrift 3, 49-63.

Iannelli, C., and E. Smyth. 2008. Mapping gender and social background differences in education and youth transitions across Europe. Journal of Youth Studies 11, no. 2: 213-232.

Idman, M. 2011. Naiset aiempaa vaativammissa tehtävissä - palkkapussi ennallaan [Women are being placed in more demanding occupations - but the pay packet stays the same]. Tieto \& Trendit 6. Tilastokeskus [Statistics Finland]. http://www.stat.fi/artikkelit/2011/art_2011-0906 001.html (accessed September 10, 2013).

Johnston, B., and B. Little. 2007. Socio-biographical background and educational path. In The careers of university graduates': Views and expertise in comparative perspectives, ed. U. Teichler, 15-40. Dordrecht: Springer.

Julkunen, R., and J. Nätti. 1999. The modernization of working times: Flexibility and work sharing in Finland. University of Jyväskylä: Jyväskylä University Printing House.

Kivinen, O., J. Hedman, and P. Kaipainen. 2007. From elite university to mass higher education:. Educational expansion, equality of opportunity and returns to university education. Acta Sociologica 50, no. 3: 231-247.

Kivinen, O., and J. Nurmi. 2009. Sukupuolten keskinäissuhteet korkeakoulutuksessa ja työmarkkinoilla - Eurooppalainen vertailu [Gender relationships in higher education and the labour market - a European comparison]. Yhteiskuntapolitiikka 74, no. 2: 149-157.

Korhonen, P, and J. Sainio. 2006. Viisi vuotta työelämässä. Monialayliopistoista vuonna 2000 valmistuneiden sijoittuminen työmarkkinoille [Five years in working life. The employment of the year 2000 graduates from multi-field universities]. AKAVA. http://www.aarresaari.net/pdf/UraraporttiNetti.pdf (accessed March 6, 2014)

Kreimer, M. 2004. Labour market segregation and the gender-based division of labour market. European Journal of Women's Studies 11, no. 2: 223-246.

Melkas, H., and R. Anker. 1997. Occupational segregation by sex in Nordic countries: An empirical investigation. International Labour Review 138, no. 3: 341-361.

Ministry of Education and Culture. 2010. Suomen väestön koulutustason vahvuudet ja heikkoudet [The strengths and weaknesses of the Finnish level of education]. Opetus- ja kulttuuriministeriön politiikka-analyysejä 3 .

http://www.minedu.fi/export/sites/default/OPM/Julkaisut/2010/liitteet/okmpol03.pdf?lang=fi (accessed May 7, 2012)

Moreau, M.-P., and C. Leathwood. 2006. Graduates' employment and the discourse of employability: A critical analysis. Journal of Education and Work 19, no. 4: 305-324.

Naumanen, P. 2002. Koulutuksella kilpailukykyä. Koulutuksen yhteys miesten ja naisten työllisyyteen ja työn sisältöön [Competiveness with education. The relation of education to the employment situation of men and women and to their work content]. Väitöskirja [Doctoral dissertation]. Turun yliopisto. Koulutussosiologian tutkimuskeskuksen raportti 57.

Nikander, T. 2010. Avioliiton suosio on hitaasti kasvanut [The favour of marriage has encreased slowly]. Tilastokatsaus 2. Tilastokeskus [Statistics Finland]. http://www.stat.fi/artikkelit/2010/art_2010-06-07_004.html?s=0 (accessed March 6, 2014).

Raffe, D. 2008. The concept of transition system. Journal of Education and Work 21, no. 4: 277 $-296$.

Prix, I. 2009. Gender and recent graduates' occupational stratification: The interactive role of the educational and employment sectors in four countries. Comparative Education 45, no. 4: 545-568. 
Puhakka, A., J. Rautopuro, V. Tuominen, and P. Vuorinen-Lampila. 2012. Current employability and graduate employment research in Finland. In Higher education research in Finland. Emerging structures and contemporary issues, eds. S. Ahola and D. Hoffman, 357-381. University of Jyväskylä. Finnish Institute for Educational Research.

Schomburg, H. 2007. The professional success of higher education graduates. European Journal of Education 42, no. 1:35-57.

Schomburg, H., and U. Teichler. 2006. Higher education and graduate employment in Europe. Results from graduate surveys from twelve countries. Springer: Dordrecht.

Smyth, E. 2002. Gender differentiation and early labour market integration across Europe. In School-to-work transition in Europe: Analyses of the EULFS 2000 Ad hoc Modul, eds. I. Kogan, and W. Müller, 31-60. Universität Mannheim: Mannheim Zentrum für Europäische Sozialforschung.

Standelmann-Steffen, I. 2008. Women, labour, and public policy: Female labour market integration in OECD countries. A comparative perspective. Journal of Social Policy 27, no. 3: 383-408.

Statistics Finland. 2008. The population of Finland in 2007. http://www.stat.fi/til/vaerak/2007/vaerak 2007 2008-03-28 tie 001 en.html (accessed October 3, 2013)

Statistics Finland. 2010. Total fertility rate 1990-2010. http://www.tilastokeskus.fi/til/synt/2010/synt 2010 2011-04-15 tie 001 en.html (accessed February 12, 2013)

Stenström, M-L. 2006. Polytechnic graduates' working life skills and expertise. In Higher education and working life: collaborations, confrontations and challenges, eds. P. Tynjälä, J. Välimaa and G. Boulton-Lewis, 89-102. Advances in Learning and Instruction Book Series. Pergamon \& EARLI, Amsterdam: Elsevier.

Støren, L.A., and C.Å. Arnesen. 2007. Women's and men's choice of higher education - what explains the persistent sex segregation in Norway? Studies in Higher Education 32, no. 2: 253-275.

Tammelin, M. 2009. Working time and family time. Experiences of the work and family interface among dual-earning couples in Finland. University of Jyväskylä. Jyväskylä Studies in Education, Psychology and Social Research 355.

Teichler, U. 1999. Research on the relationship between higher education and the world of work: Past achievements, problems and new challenges. Higher Education 38, no. 2: 169-190.

Teichler, U. 2007. Does higher education matter? Lessons from a comparative graduate survey. Europen Journal of Education 42, no. 1: 11-34.

Walby, S. 1988. Segregation in employment in social and economic theory. In Gender segregation at work, ed. S. Walby,14-28. Milton Keynes: Open University Press

Walther, A. 2006. Regimes of youth transitions. Choice, flexibility and security in young people's experiences across different European contexts. Young 14, no. 2: 119-139.

West, C., and D. H. Zimmerman. 1991. Doing gender. In The social construction of gender, eds. J. Lorber, and S. A. Farrell , 7-37. Newbury Park: Sage.

Wolbers, M. H. J. 2007. Employment insecurity at labour market entry and its impact on parental home leaving and family formation. A comparative study among recent graduates in eight European countries. International Journal of Comparative Sociology, 48(6), 481-507.

Vuorinen, P., and S. Valkonen. 2005. Ammattikorkeakoulu ja yliopisto yksilöllisten 
koulutustavoitteiden toteuttajina. [Polytechnics and universities as a path to individual educational goals.] Jyväskylän yliopisto. Koulutuksen tutkimuslaitos. Tutkimussselosteita 25. Vuorinen, P., and S. Valkonen. 2007. Korkeakoulutuksesta työelämään. Työhön sijoittuminen ja työelämävalmiudet kaupan ja tekniikan alalla. [From higher education to working life. Employment and skills and knowledge in the study fields of business administration and technology]. Jyväskylän yliopisto. Koulutuksen tutkimuslaitos. Tutkimusselosteita 37.

Vuorinen-Lampila, P., and M.-L. Stenström. 2012. Higher education graduates' employment and the uncertainty of working life. In Transitions and transformations in learning and education, eds. P. Tynjälä, M.-L. Stenström, and M. Saarnivaara. 131-151. Springer: Dordrecht. Vuorinen-Lampila, P., and S. Valkonen. 2012. Yliopisto-opiskelijoiden koulutusurat [The study careers of university students]. In Ammatillisen koulutuksen ja korkeakoulutuksen opintourat [The study careers in vocational and higher education], M.-L. Stenström. M. Virolainen, P. Vuorinen-Lampila, and S. Valkonen. 191-283. Jyväskylän yliopisto. Koulutuksen tutkimuslaitos. Tutkimusselosteita 45.

\section{Notes}

${ }^{\text {i }}$ Finland has a dual higher education system. A polytechnic is also called a University of Applied Sciences (which is the name used by the institutions themselves). In this article the term 'polytechnic' is used because it is the official name used by the Finnish Ministry of Education and Culture. In addition, it is convenient for the sake of brevity.

iii It is worth noting here that conservative ( e.g. in Southern European countries) as well as liberal regimes can have high proportions of women in paid employment and education, without there being any direct connection to gender equality as a policy pursued by the state (Esping-Andersen 1990; Walther 2006). In the Nordic countries, universalistic welfare policies also include labour market policy (labour market regime) that gives many kinds of protection to employees (e.g. to promote gender equality). (see Anxo, Bosch, and Rubery, 2010).

${ }^{\text {iv }}$ The phrases female-to-male domination and feminization refers only to the numerical majority of females to males in the field of the study in question, or in the higher education sector.

${ }^{\mathrm{v}}$ In general, gender inequality in the labour market is a complex and multidimensional problem. In the theoretical literature it has been explained via various approaches, including labour market structures (segregation and segmentation), the gender contract, and the practices and discourses by which the positions of men and women are produced and reproduced in working life and elsewhere (e.g. Beechey 1987; Bradley 1989; Hirdman 1988; Walby 1988; West and Zimmerman 1991). However, it is not possible to include all these approaches in one article.

${ }^{\text {vi }}$ These same indicators and similar operational definitions are used in Vuorinen-Lampila \& Stenström 2012.

vii The concept of 'expert' is commonly used in Finnish higher education. It was not defined in the questionnaire, since it was assumed to be a familiar term to graduates. Only $5 \%$ of the respondents chose the answer 'Don't know'. Being able to achieve an expert job is considered to be one qualitative indicator of a graduate's labour market success. In Finland the concept 'expert' is used especially in relation to a polytechnic degree. As defined by legislation, polytechnics should provide students with the practical competences needed to perform expert tasks in their field; see Stenström 2006.

viii In 2007 the percentage of Swedish-speakers in Finland was 5.5\% (Statistics Finland 2008; http://www.stat.fi/til/vaerak/2007/vaerak_2007_2008-03-28_tie_001_en.html).

ix Støren and Arnesen (2007) define male-dominated fields as those fields of study in which men comprise at least $65 \%$ of the total, with female-dominated fields being those in which women comprise at least $65 \%$ of the total. The remainder are viewed as gender-balanced. 
${ }^{\mathrm{x}}$ They have mostly placed in the public sector. The proportion of respondents working in the third sector was marginal (= $0-6 \%$ depending on degree). 
Table 1. The number of respondents by degree, the gender distribution of respondents by degree, and response rates by gender and degree.

\begin{tabular}{|l|l|l|l|l|l|l|}
\hline Degree & Number of & Gender $\%$ & \multicolumn{2}{l|}{ Response rate } \\
\cline { 3 - 7 } & $\begin{array}{l}\text { respondents } \\
n *\end{array}$ & $\begin{array}{l}\text { Women } \\
\%\end{array}$ & $\begin{array}{l}\text { Men } \\
\%\end{array}$ & $\begin{array}{l}\text { Women } \\
\%\end{array}$ & $\begin{array}{l}\text { Men } \\
\%\end{array}$ & $\begin{array}{l}\text { Total } \\
\%\end{array}$ \\
\hline Master of Science in Technology & 578 & 24 & 76 & 67 & 57 & 59 \\
\hline Bachelor of Engineering & 509 & 21 & 79 & 65 & 50 & 52 \\
\hline Master of Science in Economics & 526 & 56 & 44 & 57 & 52 & 54 \\
\hline Bachelor of Business Administration & 541 & 74 & 26 & 57 & 52 & 55 \\
\hline Total & 2154 & 44 & 56 & 59 & 53 & 55 \\
\hline $\begin{array}{l}* \\
\text { There is variation in the number of respondents by different indicators of employment success. Because not all respondents answered all } \\
\text { the questions, the amount of missing data differs by indicator. }\end{array}$
\end{tabular}


Table 2. Graduates' employment success in ten indicators by degree and gender

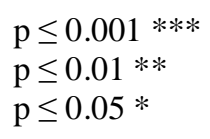

\begin{tabular}{|c|c|c|c|c|c|c|c|c|c|c|}
\hline \multirow{4}{*}{$\begin{array}{l}\text { 1.a. } \\
\text { Graduates with adequate employment at time of } \\
\text { graduation }\end{array}$} & & \multicolumn{4}{|c|}{ Business } & \multirow{3}{*}{$\begin{array}{l}\mathbf{F} \\
14.448\end{array}$} & \multirow{3}{*}{\begin{tabular}{|l|l|l|}
$\mathbf{p}$ \\
0.000
\end{tabular}} \\
\hline & \multicolumn{2}{|c|}{ MSc $(n=577)$} & \multicolumn{2}{|c|}{ BEng $(n=506)$} & \multicolumn{2}{|c|}{ MSc $(n=524)$} & \multicolumn{2}{|c|}{$\mathrm{BBA}(\mathrm{n}=540)$} & & \\
\hline & $\mathrm{F}$ & M & $\mathrm{F}$ & M & $\mathrm{F}$ & M & $\mathrm{F}$ & M & & \\
\hline & $80 \%$ & $86 \%$ & $50 \%$ & $68 \%$ & $63 \%$ & $68 \%$ & $53 \%$ & $58 \%$ & & \\
\hline & \multicolumn{8}{|c|}{ Interaction between degree $\&$ gender: } & 1.753 & 0.154 \\
\hline \multirow{5}{*}{$\begin{array}{l}\text { 1. b.. } \\
\text { Length of job search in months }\end{array}$} & \multicolumn{4}{|c|}{ Technology } & \multicolumn{4}{|c|}{ Business } & & \\
\hline & \multicolumn{2}{|c|}{$M S c(n=67)$} & \multicolumn{2}{|c|}{ BEng $(n=112)$} & \multicolumn{2}{|c|}{ M Sc $(n=146)$} & \multicolumn{2}{|c|}{ BBA $(n=128)$} & & \\
\hline & $\mathrm{F}$ & $M$ & $\mathrm{~F}$ & $M$ & $\mathrm{~F}$ & $M$ & $\mathrm{~F}$ & $M$ & 0.430 & 0.512 \\
\hline & 4.6 & 8.5 & 7.9 & 7.2 & 6.6 & 7.0 & 9.6 & 8.3 & & \\
\hline & \multicolumn{8}{|c|}{ Interaction between degree $\&$ gender: } & 1.260 & 0.288 \\
\hline \multirow{5}{*}{$\begin{array}{l}\text { 1. c. } \\
\text { Graduates unemployed after graduation }\end{array}$} & \multicolumn{4}{|c|}{ Technology } & \multicolumn{4}{|c|}{ Business } & & \\
\hline & \multicolumn{2}{|c|}{ MSc $(n=573)$} & \multicolumn{2}{|c|}{ BEng $(n=507)$} & \multicolumn{2}{|c|}{ MSc $(n=523)$} & \multicolumn{2}{|c|}{$\mathrm{BBA}(\mathrm{n}=539)$} & & \\
\hline & $\mathrm{F}$ & M & $\mathrm{F}$ & M & $\mathrm{F}$ & M & $\mathrm{F}$ & M & 9.978 & 0.002 \\
\hline & $23 \%$ & $12 \%$ & $40 \%$ & $25 \%$ & $24 \%$ & $22 \%$ & $34 \%$ & $36 \%$ & & \\
\hline & \multicolumn{8}{|c|}{ Interaction between degree and gender: } & 3.232 & 0.022 \\
\hline 2. a.1. & Technc & & & & Busine & & & & & \\
\hline Graduates in full-time employment & MSc(n & & BEng $(r$ & 466) & MSc (n & 02) & BBA $(\mathrm{n}$ & & & \\
\hline & $\mathrm{F}$ & M & $\mathrm{F}$ & M & $\mathrm{F}$ & M & $\mathrm{F}$ & M & 9.319 & 0.002 \\
\hline & $99 \%$ & $99 \%$ & $96 \%$ & $98 \%$ & $96 \%$ & $99 \%$ & $88 \%$ & $96 \%$ & & \\
\hline & Interac & on betw & degree & nd gend & & & & & 3.331 & 0.019 \\
\hline 2. a.2. & $\operatorname{MSc}(\mathrm{n}$ & & BEng (r & 466) & MSc (n & & $\mathrm{BBA}(\mathrm{n}$ & & & \\
\hline Graduates in permanent employment & $\mathrm{F}$ & M & $\mathrm{F}$ & M & $\mathrm{F}$ & M & $\mathrm{F}$ & M & 21.202 & 0.000 \\
\hline & $71 \%$ & $86 \%$ & $86 \%$ & $91 \%$ & $84 \%$ & $86 \%$ & $75 \%$ & $88 \%$ & & \\
\hline & Interac & on betw & degree & nd gend & & & & & 2.963 & 0.031 \\
\hline 2. b.. & Technc & & & & Busine & & & & & \\
\hline Employment status three years after graduation & MSc (n & 777) & BEng $(r$ & 509) & MSc (n & & $\mathrm{BBA}(\mathrm{n}$ & & & \\
\hline Paid work & $\mathrm{F}$ & M & $\mathrm{F}$ & M & $\mathrm{F}$ & M & $\mathrm{F}$ & M & 5.731 & 0.017 \\
\hline (also studies) & $90 \%$ & $95 \%$ & $84 \%$ & $90 \%$ & $92 \%$ & $94 \%$ & $84 \%$ & $86 \%$ & & \\
\hline Entrepreneur & (33\%) & \begin{tabular}{|l|}
$(28 \%)$ \\
\end{tabular} & $(15 \%)$ & $(16 \%)$ & $(20 \%)$ & $(24 \%)$ & $(14 \%)$ & \begin{tabular}{|l}
$(11 \%)$ \\
\end{tabular} & & \\
\hline Student & $1 \%$ & $4 \%$ & $0 \%$ & $3 \%$ & $1 \%$ & $5 \%$ & $2 \%$ & $4 \%$ & & \\
\hline Unemployed & $4 \%$ & $0 \%$ & $7 \%$ & $3 \%$ & $3 \%$ & $1 \%$ & $6 \%$ & $6 \%$ & & \\
\hline Other & $2 \%$ & $1 \%$ & $3 \%$ & $3 \%$ & $2 \%$ & $0 \%$ & $4 \%$ & $3 \%$ & & \\
\hline & $3 \%$ & $0 \%$ & $6 \%$ & $1 \%$ & $2 \%$ & $0 \%$ & $4 \%$ & $1 \%$ & & \\
\hline & Intera & on betw & gender & nd dec & & & & & 0.528 & 0.663 \\
\hline 2.c. & Techno & & & & Busine & & & & & \\
\hline
\end{tabular}




\begin{tabular}{|c|c|c|c|c|c|c|c|c|c|c|c|}
\hline \multirow[t]{5}{*}{ Employment sector } & \multirow{5}{*}{$\begin{array}{l}\text { Private sector } \\
\text { Public/third sector }\end{array}$} & \multicolumn{2}{|c|}{ M Sc $(n=555)$} & \multicolumn{2}{|c|}{ BEng $(n=466)$} & \multicolumn{2}{|c|}{ M Sc $(n=500)$} & \multicolumn{2}{|c|}{ BBA $(n=474)$} & \multirow[b]{2}{*}{18.883} & \multirow[b]{2}{*}{0.000} \\
\hline & & $\mathrm{F}$ & M & $\mathrm{F}$ & $M$ & $\mathrm{~F}$ & M & $\mathrm{F}$ & M & & \\
\hline & & $62 \%$ & $76 \%$ & $79 \%$ & $83 \%$ & $70 \%$ & $77 \%$ & $73 \%$ & $86 \%$ & & \\
\hline & & $38 \%$ & $24 \%$ & $21 \%$ & $17 \%$ & $30 \%$ & $23 \%$ & $27 \%$ & $17 \%$ & & \\
\hline & & \multicolumn{8}{|c|}{ Interaction between degree $\&$ gender: } & 1.091 & 0.352 \\
\hline \multirow{2}{*}{\multicolumn{2}{|c|}{$\begin{array}{l}\text { 3. a. } \\
\text { Position in employer's organization }\end{array}$}} & \multicolumn{4}{|c|}{ Technology } & \multicolumn{4}{|c|}{ Business } & & \\
\hline & & \multicolumn{2}{|c|}{ M Sc $(n=553)$} & \multicolumn{2}{|c|}{ BEng $(n=465)$} & \multicolumn{2}{|c|}{ M Sc $(n=496)$} & \multicolumn{2}{|c|}{ BBA $(n=474)$} & & \\
\hline & \multirow{6}{*}{$\begin{array}{l}\text { Management level } \\
\text { Clerical employee } \\
\text { Shop-floor level } \\
\text { Other }\end{array}$} & $\mathrm{F}$ & M & $\mathrm{F}$ & $\mathrm{M}$ & $\mathrm{F}$ & M & $\mathrm{F}$ & $M$ & 27.521 & 0.000 \\
\hline & & $10 \%$ & $26 \%$ & $14 \%$ & $21 \%$ & $22 \%$ & $30 \%$ & $9 \%$ & $22 \%$ & & \\
\hline & & $79 \%$ & $64 \%$ & $59 \%$ & $63 \%$ & $59 \%$ & $56 \%$ & $60 \%$ & $50 \%$ & & \\
\hline & & $7 \%$ & $7 \%$ & $23 \%$ & $12 \%$ & $8 \%$ & $6 \%$ & $29 \%$ & $25 \%$ & & \\
\hline & & $4 \%$ & $3 \%$ & $4 \%$ & $4 \%$ & $11 \%$ & $8 \%$ & $2 \%$ & $3 \%$ & & \\
\hline & & \multicolumn{8}{|c|}{ Interaction between gender and degree: } & 1.041 & 0.373 \\
\hline \multirow{5}{*}{\multicolumn{2}{|c|}{$\begin{array}{l}\text { 3. b. } \\
\text { Percentage of graduates working as experts }\end{array}$}} & \multicolumn{4}{|c|}{ Technology } & \multicolumn{4}{|c|}{ Business } & & \\
\hline & & \multicolumn{2}{|c|}{ M Sc $(n=551)$} & \multicolumn{2}{|c|}{ BEng $(n=464)$} & \multicolumn{2}{|c|}{ M Sc $(n=498)$} & \multicolumn{2}{|c|}{ BBA $(n=475)$} & & \\
\hline & & $\mathrm{F}$ & $\mathrm{M}$ & $\mathrm{F}$ & $\mathrm{M}$ & $\mathrm{F}$ & $\mathrm{M}$ & $\mathrm{F}$ & $M$ & 27.609 & 0.000 \\
\hline & & $88 \%$ & $90 \%$ & $63 \%$ & $84 \%$ & $85 \%$ & $89 \%$ & $60 \%$ & $74 \%$ & & \\
\hline & & \multicolumn{8}{|c|}{ Interaction between gender and degree: } & 5.015 & 0.002 \\
\hline \multirow{5}{*}{$\begin{array}{l}\text { 3.c. } \\
\text { Good correspondence } \\
\text { employment }\end{array}$} & \multirow{5}{*}{ between education and } & \multicolumn{4}{|c|}{ Technology } & \multicolumn{4}{|c|}{ Business } & & \\
\hline & & \multicolumn{2}{|c|}{$\mathrm{MSc}(\mathrm{n}=558)$} & \multicolumn{2}{|c|}{ BEng $(n=466)$} & MSc & 02) & BBA ( & 75) & & \\
\hline & & $\mathrm{F}$ & M & $\mathrm{F}$ & $\mathrm{M}$ & $\mathrm{F}$ & M & $\mathrm{F}$ & $M$ & 3.227 & 0.073 \\
\hline & & $92 \%$ & $93 \%$ & $74 \%$ & $86 \%$ & $88 \%$ & $91 \%$ & $75 \%$ & $72 \%$ & & \\
\hline & & Inter & n bety & gend & id deg & & & & & 2.763 & 0.041 \\
\hline
\end{tabular}

\section{Abbreviations of degrees:}

\section{Technology field:}

MSc = M aster of Science in Technology (/Architecture); BEng = Bachelor of Engineering Business field:

$\mathrm{MSC}=\mathrm{M}$ aster of Science in Economics and Business Administration; BBA =Bachelor of Business Administration 
Table 3. Summary of employment success indicators, statistically significant differences between genders, and interactions between gender and degree.

\begin{tabular}{|c|c|c|c|}
\hline Indicator & $\begin{array}{l}\text { Male-female } \\
\text { difference } \\
\text { (\%-points) }\end{array}$ & $\begin{array}{l}95 \% \\
\text { confidence } \\
\text { interval }\end{array}$ & $\begin{array}{l}\text { Sig by gender and } \\
\text { sig of interactions } \\
\text { (in favour of) }\end{array}$ \\
\hline Adequate employment at time of graduation & 13 & 9,17 & $* * *$ (men) \\
\hline Length of job search & $-0.27^{1}$ & $-1.8,1.2$ & n.s. \\
\hline Unemployed after graduation & -9 & $-12,-5$ & ** (men) \\
\hline $\begin{array}{c}\text { - Interaction: MSc (tech.) } \\
\text { BEng } \\
\text { MSc (business) } \\
\text { BBA }\end{array}$ & $\begin{array}{l}-11 \\
-15 \\
-2 \\
2^{2}\end{array}$ & $\begin{array}{l}-18,-5 \\
-24,-5 \\
-10,5 \\
-7,11\end{array}$ & $*(\text { men }+ \text { degree })^{3}$ \\
\hline Full-time employment & 5 & 3,7 & ** (men) \\
\hline $\begin{array}{c}\text { - Interaction: MSc (tech.) } \\
\text { BEng } \\
\text { MSc (business) } \\
\text { BBA }\end{array}$ & $\begin{array}{l}0 \\
2 \\
3 \\
8\end{array}$ & $\begin{array}{l}-2,2 \\
-3,6 \\
0,5 \\
2,14\end{array}$ & $*(\text { men }+ \text { degree })^{4}$ \\
\hline Permanent employment & 9 & 5,12 & $* * *$ (men) \\
\hline $\begin{array}{c}\text { Interaction: MSc (tech.) } \\
\text { BEng } \\
\text { MSc (business) } \\
\text { BBA }\end{array}$ & $\begin{array}{l}15 \\
5 \\
2 \\
13\end{array}$ & $\begin{array}{l}8,23 \\
-1,12 \\
-4,8 \\
4,20\end{array}$ & $*(\text { men }+ \text { degree })^{5}$ \\
\hline Employment status (paid work) & 4 & 2,7 & $*$ (men) \\
\hline Employment sector & 9 & 5,12 & $* * * . .6$ \\
\hline Organizational status & $11^{7}$ & 7,14 & $* * *$ (men) \\
\hline Working as an expert & 13 & 10,17 & $* * *$ (men) \\
\hline $\begin{array}{c}\text { - Interaction: MSc (tech.) } \\
\text { BEng } \\
\text { MSc (business) } \\
\text { BBA }\end{array}$ & $\begin{array}{l}2 \\
21 \\
4 \\
14\end{array}$ & $\begin{array}{l}4,8 \\
13,31 \\
-2,10 \\
5,23\end{array}$ & ** (men +M asters) \\
\hline Good correspondence between education and job & 6 & 3,9 & n.s. \\
\hline $\begin{array}{c}\text { - Interaction: M Sc (tech.) } \\
\text { BEng } \\
\text { MSc (business) } \\
\text { BBA }\end{array}$ & $\begin{array}{l}1 \\
12 \\
3 \\
-3\end{array}$ & $\begin{array}{l}-3,6 \\
4,21 \\
-3,8 \\
-12,6\end{array}$ & $*(\text { men }+ \text { degree })^{8}$ \\
\hline
\end{tabular}

1 Months

2 M en have been unemployed more often than women.

3 In favour of master degree holders and male Bachelors of Engineering.

4 In favour of all other graduates than female Bachelors of Business Administration.

5 In favour of all other graduates than female M asters of Science in Technology and female Bachelors of Business Administration.

$6 \mathrm{M}$ en are placed more in the private sector, women in the public sector. Cannot be perceived as being in favour of one or other gender.

7 Indicates management level

8 In favour of all others than women with Bachelor of Engineering degree.

9 Women have good correspondence more often than men. 